\title{
The application of generalising judgements and their influence on the images of selected Polish columnists (a constructivism-focussed quantitative and qualitative approach) ${ }^{1}$
}

\section{Introduction}

The goal of the text is to define the image-based characteristics an author can communicate by expressing generalising judgements, and, most of all, to attempt to establish the possible differences between generalisations depending on the image characteristic being communicated (what type of generalisation should be used for communicating a specific characteristic). The following research constitutes only a portion of a much bigger whole, the aim of which is to verify what image of an author of a message can be communicated using verbal actions.

Upon reading a text by one of the four columnists, the respondents assigned image characteristics, and later indicated those fragments of the text which had constituted the basis for identifying the selected characteristic. The collected quotations were used as material for discourse analysis, which enabled me to identify the methods, modes of communication, and communication markers (e.g. using highly evaluative lexis and detailed descriptions, formulating stipulations and proposals, and many more) important for each image characteristic (e.g. intelligent, critical, anti-clerical). Said markers included generalisations: the formulation of general judgements which might appear universal. Since the same marker (i.e. generalisation) appeared as a means for communicating several image char-

*Ph.D., e-mail: anna.baranska@uni.lodz.pl; Chair of Communication Theory and Practice, Department of Journalism and Social Communication, University of Lodz.

${ }^{1}$ The article was developed as part of the research conducted within the project entitled "Analiza dyskursu na materiale empirycznym w kontekście badania wizerunku", co-financed within the framework of a limited subsidy for research, and the development of young scientists and Ph.D. candidates, project code: B1711300001711.02. 
acteristics, it seemed interesting what was the difference between a generalisation communicating, e.g. intelligence, and a generalisation communicating, e.g. a critical characteristic.

It is apparent that the issue of generalised judgements has not constituted the main subject of the study of image and the methods of its verbal communication. Yet in the course of the analysis, it became so visible, and thus significant, that I decided to study it more closely and attempt to define the different manners of how generalisations function depending on the image characteristic they express.

I considered the issue interesting also because, even though there has been extensive image research, mainly using quantitative research in its marketing focus (e.g. in planning and verifying the image assumptions of product brands and services ${ }^{2}$ ), there have been few studies aiming to define image and the methods of communicating it when an author of a text raises various problems, but does not refer to herself/himself. The relationship between an author and the evaluation of her/his message has been studied empirically ${ }^{3}$. In terms of ethics (ethos of the speaker), the notion of reliability of the sender is also analysed by rhetoric studies $^{4}$ (Corbett, Connors 1998). The issue of self-presentation in a social interaction situation is raised by anthropology and social psychology $y^{5}$. Some of the latest studies focus on image communicable through words ${ }^{6}$, and on the influence of the genre of an expression on an image ${ }^{7}$. It is difficult to indicate a study

2 Vide: N. Malhotra, J. Hall, M. Shaw, P. Oppenheim, "Marketing Research: An applied orientation", 3rd ed., Pearson Education Australia Pry Ltd., New South Wales, Australia 2005. Also, e.g.: A. Wilson, R. Johns, K.W. Miller, R. Pentecost, "Marketing research: an integrated approach: solving business problems. The value of marketing research", Pearson Education Australia Pry Ltd., New South Wales, Australia 2010.

${ }^{3}$ On the influence of an author's sex on the reception of a text: H.A. White, J.L. Andsager, "Newspaper Column Readers' Gender Bias: Perceived Interest and Credibility", Journalism \& Mass Communication Quarterly, Vol. 68, Issue 4, 1991, pp. 709-718. On the importance of an author's reliability for evaluating her/his statements: L.C. Hovland, C.W. Weiss, "The influence of source credibility on communication effectiveness", Public Opinion Quarterly 1951, Issue 15, pp. $635-650$.

${ }^{4}$ Vide e.g.: E.P.J. Corbett, R.J. Connors, "Classical Rhetoric for the Modern Student", $4^{\text {th }}$ ed., Oxford University Press, New York 1998.

${ }^{5}$ Vide e.g.: E. Goffman, "The Presentation of Self in Everyday Life", Anchor Books, New York 1959 and, e.g. M. Leary, "Self-presentation: Impression Management And Interpersonal Behavior", Westview Press, Boulder 1996.

${ }^{6}$ E.g. A. Barańska-Szmitko, "Image from Words. What do Authors of Columns Communicate about Themselves to their Readers?", Humanities \& Social Sciences Review 2014, Vol. 3, No. 4, pp. 67-74; or: ibid., "Means of Communicating an Image of Being 'Engaged' and 'A Realist' in Newspaper Columns: Results of Empirical Research", Humanities and Social Sciences Review 2016, Vol. 6, No. 1, pp. 127-136.

${ }^{7}$ Vide A. Barańska-Szmitko, "The Capacities and Limitations of the Newspaper Column as a Tool for Creating the Image of Its Author", Acta Universitatis Lodziensis. Folia Litteraria Polonica 2016, No. 5 (35), pp. 115-129. 
in which the use of generalisation is considered in the context of the influence on communicating image characteristics, and since the device seems quite common, it deserves closer consideration.

\section{Theoretical perspective}

In the study, I assumed the theoretical perspective of rational constructivism ${ }^{8}$, in which the division into an expression and a message is important. While expressions constitute "material data, physically present and transported vehicles which, even if frozen, offer the opportunity to produce messages or directly deliver the basis for that operation", messages are created based on the expressions as "(re) constructive results of the freely understood perception processes of individual interpreters [...], which form through cognitive-emotional operations in individual minds" ${ }^{\prime 10}$. Thus an expression has the potential to become a message in the reception process. An interpreter can create a message from an expression (e.g. a gesture, a word or a sound). In this text (to ensure higher clarity), the term expression will be reserved solely for the material data of the natural language system. The characteristic assigned to each columnist constitutes a message constructed based on an expression, or more precisely, applicable fragments of her/his column.

In the analysis, the constructivist division into speaking and communicating proved useful. According to it "speaking applies to that which is spoken" while "communicating applies to how it is spoken and what is communicated by what and how one says something"11. Therefore, one can "say" one is a literature expert and particularly values the period of the Italian Middle Ages and its leading author, Shakespeare, for innovative narrative solutions introduced in Jesus Christ Superstar. In that situation what was said was nothing more than the above words, yet what was communicated was extensive literary ignorance.

The following results focussed on the message, i.e. the characteristics communicated by the authors being (re)created; the expression and speaking were

\footnotetext{
${ }^{8}$ Vide: M. Fleischer, “Ogólna teoria komunikacji”, Wydawnictwo Uniwersytetu Wrocławskiego, Wroclaw 2008.

${ }^{9}$ M. Fleischer, "Konstrukcja rzeczywistości 2", Wydawnictwo Atut, Wroclaw 2008, p. 60 [translated into English from Polish].

${ }^{10}$ Ibid. Cf.: A. Awdiejew, G. Habrajska, "Obrazy ideacyjne w interpretacji tekstu”, in: "Rozmowy o komunikacji 5. Kategorialne aspekty komunikacji”, G. Habrajska (ed.), Primum Verbum, Lodz 2011, p. 57.

${ }^{11}$ M. Fleischer, “Typologia komunikacji”, Primum Verbum, Lodz 2012, p. 29. Cf. experiment-based linguistic studies, e.g.: W. Miodunka, "Teoria pól językowych. Społeczne i indywidualne ich uwarunkowania", PWN, Warsaw 1982; W. Pisarek, "Eksperyment - metoda nie tylko fonetyczna", Biuletyn PTJ 1969, Vol. 28, pp. 181-188.
} 
highlighted as they applied to one of the methods of speaking which develops at the level of an expression in the form of a generalisation.

A generalisation itself is understood as a judgement universal or general in nature, often timeless, expressing an opinion on the potential of maxims which indicate certain characteristics, and mechanisms of human nature, culture or nation.

\section{Methodology and study procedure}

Constructivism appropriates sociological methods "as closest to communication science"12. I used the so-called mixed method ${ }^{13}$, or, using another terminological framework, I used a triangulation of methods ${ }^{14}$ combining quantitative and qualitative perspectives. In the first part of the study, I conducted an experiment, in the second part, I conducted a discourse analysis.

Among the quantitative methods, I found the experiment formula ${ }^{15}$ useful; the variable was the information on a given author's name and her/his photograph. The control group received the text of a column in the form of a printout on a white A4 sheet of paper. The experiment group received photocopies of the page with the text from the weekly in which it was published, which apart from the text also included the photograph of its author and her/his identification. In both groups, the respondents were asked to read the expressions, and define the image characteristics of the respective authors. The group with the anonymous text answered the question: "Based on the column you have just read, how would you describe the author of the text?". In the group where the identity of the author of the text was overt, the question did not include the word author but the author's name and surname. The instructions were printed on an A5 sheet of paper in order to limit the responses to only the most emphatic ones. In order to increase result comparability, I suggestively included five bullet points to specify any five image characteristics. In the following stage, on another A5 sheet of paper, the following instruction was included: "For each of the characteristics of the author of the column, please copy from the text words/sentences/fragments which became the basis for identifying those respective characteristics". If the identity of an author was overt, the instruction once again included the relevant names. The answer sheet included

\footnotetext{
${ }^{12}$ M. Fleischer, "Konstrukcja...", p. 101.

13 J.W. Creswell, "Research design: Qualitative, Quantitative and Mixed Methods Approaches", 4th. ed., Sage, Los Angeles, London, New Delhi, Singapore, Washington D.C. 2014, pp. 215-240.

${ }^{14}$ U. Flick, "Designing Qualitative Research", Sage, Los Angeles, London, New Delhi, Singapore, Washington D.C. 2007, p. 38.

${ }^{15}$ E. Babbie, "The Practice of Social Research", 9th. ed., Wadsworth/Thomson Learning, Belmont, CA 2001, pp. 245-266.
} 
points 1-5 with applicable space for writing down the quotes from the column which expressed the image characteristics assigned by the respondents.

In the study, I used the texts of four columnists whom I selected to present various ideological attitudes and who regularly discuss different issues ${ }^{16}$. I used the column, which, in Poland, when compared to other journalistic forms, offers its author considerable freedom for expressing her/his personality, and almost unlimited thematic and stylistic freedom ${ }^{17}$. Thanks to the periodic nature of columns, it was possible to use several texts by the same author. Due to the influence of periodisation on the content and the form of the texts, I used columns published within the same period, i.e. every week.

The study was conducted in three time stages simultaneously for all four authors: in the spring of 2012 (May/June), spring of 2013 (June), and autumn of 2013 (October). In each period, the same number of respondents read the same number of columns by the respective authors within the same number of variants of the entire study and with an identical arrangement of instructions. By applying the proportionality principle, I was able to achieve comparable results. The division of the experiment into three stages enabled me to use texts which were diverse in terms of their focus (thus I avoided fixing the results with the themes of the expressions), and a large number of different titles, while the actual contents did not lose their communicative nature (a column applies to current themes, which is why if one was to read a few-months-old text, the expression could be unclear) ${ }^{18}$.

I invited first and second year students of journalism and Polish studies from several Polish universities to voluntarily participate in the study ${ }^{19}$. I included only those two areas of study as I assumed they ensured optimal linguistic competence

${ }^{16}$ The widely considered cultural focus was represented by Krzysztof Varga (collaborator of the Duzy Format supplement to Gazeta Wyborcza) and Piotr Zaremba (collaborator of $W$ sieci, previously of Sieci and Uważam Rze), the former being quite liberal, the latter conservative. The social-political focus was presented by Magdalena Środa (Wprost weekly) and Szymon Hołownia (columnist at Rzeczpospolita, previously at Wprost and Newsweek); Magdalena Środa displays anti-clerical feminism, while Szymon Hołownia discusses religious issues.

${ }^{17}$ Vide the definition of a column in the Polish tradition: A. Barańska-Szmitko, "The Capacities and Limitations of the Newspaper Column as a Tool for Creating the Image of Its Author", Acta Universitatis Lodziensis. Folia Litteraria Polonica, 2016, No. 5 (35), p. 115-129, where the author offered a summary of the observations of several Polish researchers (e.g.: M. Wojtak, P. Statsiński, E. Chudziński, K. Wolny-Zmorzyński, A. Kaliszewski, W. Furman, E. Sławkowa, A. Niczyperowicz et al.), noting that the main constructing features of a column in the Polish press include: subjectivity of the author's views, stylistic freedom, thematic freedom while respecting the principle of topicality of the issues raised.

${ }^{18}$ At a given stage, I used the seven most recently published texts by each author. Considering the total number of the texts, I am not quoting specific titles of the texts. At the end of the article, I included the titles of the quoted columns.

${ }^{19}$ University of Łódź, University of Wrocław, Kazimierz Wielki University in Bdygoszcz, University of Warsaw, Adam Mickiewicz University in Poznań. 
and the required level of eloquence. I did not approach the students of later years as I expected them to possess too high competences and knowledge in terms of linguistics, communication and journalistic genres. The homogeneity of the sample ensures comparable results. The time assigned for performing the tasks was unlimited, though it rarely exceeded 15-20 minutes.

By utilising the formula of an experiment, I was able to verify whether the knowledge of who the author is had any significance for the construction of the columnist's image by the reader, but, most of all, I was able to specify which image characteristics were communicable using expressions within the system of natural language. The task of writing down fragments led to the collection of linguistic material - sets of fragments associated with specific image characteristics. A discourse analysis of those sets enabled me to identify communication markers used for communicating each of the characteristics indicated by the respondents. The recurrence of some markers (e.g. generalisations) could form the basis for further analyses.

I utilised constructivist discourse analysis, thus I mainly focussed on the fact that "we are interested [...] only in the possible influence of a given expression, the result the expression may produce; $[. .$.$] influence [. .$.$] which is binding (for$ discourse participants), typical, commonly used" ${ }^{20}$. If one considers as the basis the focus on that which is typical or common, it is a good idea to include respondents in the study process and subject their answers to quantitative processing $^{21}$. Furthermore, concentrating on the communicative effect excludes from the analysis the intentions of the sender of the expression. Therefore, I focussed on respondent answers, not on the interpretations of what image a given author of a given text might have wished to communicate.

\section{The results}

I organised the following discussion in such a way to first present the general figures, then to list and describe the modes of functioning of generalisations visible in the quotations listed by the respondents, and finally to indicate particular trends and relations with the image characteristic being communicated.

The results which are analysed below were extracted from 504 surveys filled out by 504 participants of the study, half of whom belonged to the variant in which the identity of the authors was know, the other half to the variant in which the respondents read an anonymous text. In each variant at each of the three stages, three respondents read 7 different columns by each of the four authors ( 2 study

\footnotetext{
${ }^{20}$ M. Fleischer, "Konstrukcja...", p. 99.

${ }^{21}$ Vide ibid., pp. 49-111.
} 
variants $\mathrm{x} 3$ stages $\mathrm{x} 7$ most recent columns $\mathrm{x} 4$ authors $\mathrm{x} 3$ readings $=504$ surveys). They assigned all columnists various attributes (e.g. intelligent, ironic, conservative, witty, anti-clerical, traveller, etc.) with various markers communicating related characteristics. Based on my calculations, generalising judgements appeared in respondent answers in 98 quotations (in 504 surveys, respondents indicated fragments which featured generalisations 98 times). The respondents associated those quotations with the following image characteristics: intelligent, bluntly states her/his bold judgements, critical, insightful, writes in an interesting way, realist, frank. The specified characteristics were presented in the following table (vide: the first column from the left) in association with the number of quotations in which generalisations appeared (the sixth column from the left), and having considered the figures for each columnist in both study variants (columns from the second to the fifth from the left), and in specific variants independently (data for overt author and anonymous in the following parts of the Table 1).

Table 1. Image characteristics communicated through generalisations and the uantitative distribution of the findings

\begin{tabular}{|c|c|c|c|c|c|c|c|c|c|c|c|c|c|c|c|}
\hline Generalisation & $\stackrel{*}{2}$ & $\stackrel{N}{0}$ & $\sum^{n}$ & $\sqrt{2}$ & 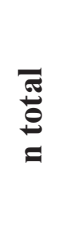 & $\vec{z}$ & $\stackrel{N}{N}$ & $\sum$ & $\bar{a}$ & 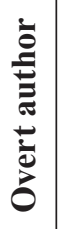 & $\vec{z}$ & $\hat{N}$ & $\sum$ & $\bar{n}$ & 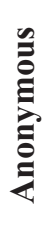 \\
\hline intelligent & 9 & 7 & 4 & 11 & 31 & 4 & 2 & 2 & 5 & 13 & 5 & 5 & 2 & 6 & 18 \\
\hline $\begin{array}{l}\text { bluntly states } \\
\text { her/his bold } \\
\text { judgements }\end{array}$ & 4 & 5 & 7 & 10 & 26 & 4 & 3 & 6 & 6 & 19 & 0 & 2 & 1 & 4 & 7 \\
\hline critical & 5 & 1 & 1 & 9 & 16 & 2 & 1 & 1 & 7 & 11 & 3 & 0 & 0 & 2 & 5 \\
\hline insightful & 3 & 0 & 1 & 3 & 7 & 2 & 0 & 0 & 0 & 2 & 1 & 0 & 1 & 3 & 5 \\
\hline $\begin{array}{l}\text { writes in an } \\
\text { interesting way }\end{array}$ & 1 & 3 & 1 & 2 & 7 & 0 & 2 & 0 & 2 & 4 & 1 & 1 & 1 & 0 & 3 \\
\hline realist & 3 & 0 & 2 & 1 & 6 & 1 & 0 & 1 & 0 & 2 & 2 & 0 & 1 & 1 & 4 \\
\hline frank & 2 & 1 & 1 & 1 & 5 & 1 & 1 & 1 & 0 & 3 & 1 & 0 & 0 & 1 & 2 \\
\hline Total & 27 & 17 & 17 & 37 & 98 & 14 & 9 & 11 & 20 & 54 & 13 & 8 & 6 & 17 & 44 \\
\hline
\end{tabular}

${ }^{*}$ Capital letters refer to the columnists' initials: KV - Krzysztof Varga, PZ - Piotr Zaremba, MŚ - Magdalena Środa, SH - Szymon Hołownia.

Source: own study.

The study of the material up to that point did not enable me to identify any differentiating features of the study variants. Generalisations function similarly 
regardless of whether the author of a text was anonymous or known to the reader. Therefore, in the following examples/quotations, I did not include the division into the study variants.

I shall assign the quantitative differences between the variants to the influence of extra-textual elements (photographs, associations with a given name). It should be stressed, though, that the differences were minor. The proportions for respective variants were the following: 54 to 44 quotations which included generalisations. In the case of Magdalena Środa, a fragment which included a generalisation was quoted 11 times when her identity was known and only 6 times when her identity was covert. The differences were even lower in the case of the remaining columnists. Therefore, generalising judgements are more or less equally identified regardless of whether the reader knows the author or not, which might suggest that generalisations are resistant to external influence, such as photographs or extratextual knowledge about the author.

The analysis of the quotations indicated that generalisations could be fulfilled through the presentation of a rule, and expressing an evaluation or a taboo judgement. They might be used to formulate stipulations; some of their more characteristic qualities also include negation or the grammatical form of the first person plural.

Generalisations fulfilled in the form of a rule consisted of opinions with a particularly universal nature presenting a certain principle, law or norm governing people and the world, e.g.

- The love of the nation is a curse which one cannot overcome (KV, DF, 29 Mar 2012) ${ }^{22}$;

- Not everyone who has a brain is intelligent, and not everyone who is a conscious being thinks (MŚ, W, 19/2012).

The rule was typical for the intelligent image characteristic, i.e. that manner of fulfilling the generalised judgement was the most common in the case of that characteristic.

Evaluation was also typical for generalisations. It was expressed in two ways: through evaluative lexis and through the use of irony. Marked vocabulary was visible, e.g. in the following fragments:

- What we have today is mainly gibberish used to conceal mental helplessness (PZ, S,18/2013);

- The Church is not the problem, rather a few blind bureaucrats. With whom (regardless whether they are clergymen or laymen) there is always the problem

${ }^{22}$ All examples possess actual wording, i.e. constitute direct reflections of respondent notes included in the survey cards. In the parenthesis after the below-quoted fragments, I included the initials of their authors (MŚ - Magdalena Środa, SH - Szymon Hołownia), an abbreviated name of the periodical which published the texts (DF - Duzy Format, W - Wprost, $\mathrm{N}$ - Newsweek, $\mathrm{R}$-Rzeczpospolita), from which the quotations were taken, as well as the issue of a given weekly (year of issue preceded by a forward slash) or the date of publication of a given copy of a daily. 
that in order to stop following old ruts what is needed is an explosion with human casualties ( $\mathrm{SH}, \mathrm{R}, 05-06.10 .2013$ ).

Irony was also present, mainly based on hyperbolisation. E.g.:

- The need to possess a current national hero is so strong that the Polish nation is on a constant look-out (KV, DF, 29.03.2012);

- Its [Catholic Church's - A.B.S.] ministers are the perfect managers that utilise legal loopholes, the servile attitudes of decision-makers and the general obedience of the people to increase the Church's wealth (...) [build temples, seize land, intimidate the authorities with the cross, and get rich] (MŚ, W, 20/2013).

It must be stressed that evaluating lexis and irony used as means based on evaluation constituted the largest group of instances of generalisations as well as the most diverse and the least specific (i.e. they did not possess a tendency for communicating only one characteristic). A negative evaluation was their common property, yet the degree of markedness of the specific words and the resulting strength of the criticism being expressed were not the same for each characteristic. Lexis and irony exerted a considerably greater influence on the object being described when they communicated the critical characteristic, and significantly weaker when they were the basis of assigning the intelligent or insightful characteristics. Though the rule proved clearly typical for one of the image characteristics (intelligent), evaluation appeared in four out of seven characteristics communicated by generalisations, yet it did not reveal any particular tendencies in terms of communicating one of those; however, in terms of quality, the most negatively marked evaluation was associated with the critical characteristic.

That is a phenomenon reverse to taboo, the violation of which proves typical for only one image characteristic. There also appeared generalisations which violated the communicative taboos (typical for Poland ${ }^{23}$ ), regarding the Catholic Church and its representatives, abortion/death, and public evaluation of politicians, e.g.:

- That is not only a matter of rhetorical hygiene. The lack of dialogue is killing the Church (SH, N, 20/2012);

- Women are forced to bear children, yet no one cares about those already born (MŚ, W, 11/2013);

- The media serve politicians, while politicians serve the media (MŚ, W, 22/2013).

Generalisations based on violating taboos were relevant only for the bluntly states her/his bold judgements image characteristic.

\footnotetext{
${ }^{23}$ Vide: A. Dąbrowska, “Zmiany obszarów podlegających tabu we współczesnej kulturze”, in: "Język a Kultura. Tom Jubileuszowy. Tom 20", A. Dąbrowska (ed.), Wydawnictwo Uniwersytetu Wrocławskiego, Wroclaw 2008, pp. 173-196. Also: M. Fleischer, “Obszar tabu w systemie polskiej kultury", in: "Literatura, kultura, komunikacja. Księga Pamiątkowa ku czci Profesora Jerzego Jastrzębskiego w 60. rocznicę urodzin", M. Graszewicz, K. Stasiuk (eds.), Wydawnictwo Uniwersytetu Wrocławskiego, Wroclaw 2006, pp. 283-300.
} 
Among the generalisations quoted by the respondents, there also appeared a type which could be defined as: a stipulation. Those were opinions regarding the world with an underlying indication of what should be changed or avoided, e.g.:

- Christians today must focus on being the Scripture (SH, W, 9/2013);

- order must be introduced in the world where someone made a mess of everything, generalisations are absolutely pointless; if you fuel the flames of emotions, you might get burnt (SH, R, 05-06.10.2013).

Stipulations appeared only in Szymon Hołownia's texts, an author who raises social-political issues which he discusses in the context of Christian values.

Another method of introducing generalisations as an image marker is based on the length of an expression. There were fragments which offered a short and negative summary of a phenomenon, e.g.

- Now, there is less and less space for imagination (PZ, S, 16-17/2013);

- What about the essence? We know nothing about it (SH, W, 11/2013).

Such short expressions pejoratively evaluating a phenomenon or a person appeared in the case of characteristics based on criticism (critical, bluntly states her/ his bold judgements). Though in neither of the cases did they constitute a special device typical of a respective characteristic, they did not appear in the case of other characteristics.

In the collected generalising judgements, there also appeared negations, i.e. opinions based on denying something, e.g.:

- We do not possess a sense of humour. We only possess a sense of honour (KV, DF, 29.05.2013);

- Terrorism has no address nowadays (SH, R, 28-29.09.2013).

Interestingly enough, all quotations in that group communicated only one image characteristic: realist.

The final form of the functioning of generalisations identified was a general judgement based on the 1st person plural form, i.e. applying to the abstract we, e.g.:

- We are all children of God, Nature, culture, and science. The stigma disgraces mainly the one who brands with it, not her/his victim (MŚ, W, 16/2013);

- because we need our brains less than our livers; many people cope perfectly without any brains (KV, DF, 19.09.2013).

All the quotations in the group applied only to the frank image characteristic.

\section{Summary and conclusions}

As indicated by the above analysis, generalisations in columns function according to several modes. The following table includes quantitative data. The figures designate the number of quotations fulfilled by a given mode of the function- 
ing of generalisations (rules, evaluation, stipulation, etc.) in relation to specific image characteristics (intelligent, bluntly states her/his bold judgements, etc.) The largest group consisted of general judgements which offered evaluations through evaluating lexis or irony $(27.55 \%$ of all fragments which included generalising judgements). That type of general opinion appeared in several image characteristics. It also differs in terms of quality: the strength of a pejorative evaluation depends on the image characteristic being communicated. The strongest negative evaluations appeared for the critical characteristic. A rule was the second most common mode of communicating image (23.47\%) using generalisations and it was most often used for expressing intelligence. Taboo had the third largest presence among the expressions of general judgements, and was only related to the bluntly states her/his bold judgements characteristic. A stipulation (15.31\% of quotations), similarly to an evaluation, applied to several image characteristics, however, that type of a generalisation could be a literary quality of a columnist or the theme (religion) as it only applied to one author: Szymon Hołownia. Negations $(6.12 \%)$ and expressions in the 1st person plural (5.1\%) were related to communicating only the characteristics of: realist and frank respectively.

Table 2. Quantitative distribution of quotations representing generalisations considering the image characteristics being communicated

\begin{tabular}{|c|c|c|c|c|c|c|c|c|c|}
\hline \multirow{2}{*}{$\begin{array}{l}\text { Type of genera- } \\
\text { Image } \\
\text { characteristic }\end{array}$} & \multirow[b]{2}{*}{ 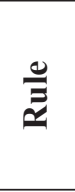 } & \multicolumn{2}{|c|}{ Evaluation } & \multirow{2}{*}{ 离 } & \multirow[b]{2}{*}{ 苗 } & \multirow{2}{*}{ 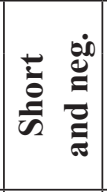 } & \multirow{2}{*}{$\stackrel{\infty}{\stackrel{00}{2}}$} & \multirow{2}{*}{$\frac{\infty}{\grave{\omega}} \dot{\bar{\alpha}}$} & \multirow[b]{2}{*}{ 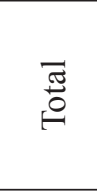 } \\
\hline & & 离 & $\stackrel{\vec{E}}{E}$ & & & & & & \\
\hline intelligent & 15 & 7 & 5 & 4 & 0 & 0 & 0 & 0 & 31 \\
\hline $\begin{array}{l}\text { bluntly states her/ } \\
\text { his bold judge- } \\
\text { ments }\end{array}$ & 2 & 0 & 0 & 3 & 15 & 6 & 0 & 0 & 26 \\
\hline critical & 0 & 4 & 4 & 4 & 0 & 4 & 0 & 0 & 16 \\
\hline insightful & 3 & 4 & 0 & 0 & 0 & 0 & 0 & 0 & 7 \\
\hline $\begin{array}{l}\text { writes in an inte- } \\
\text { resting way }\end{array}$ & 3 & 2 & 1 & 1 & 0 & 0 & 0 & 0 & 7 \\
\hline realist & 0 & 0 & 0 & 0 & 0 & 0 & 6 & 0 & 6 \\
\hline frank & 0 & 0 & 0 & 0 & 0 & 0 & 0 & 5 & 5 \\
\hline total & 23 & 18 & 10 & 12 & 15 & 9 & 6 & 5 & 98 \\
\hline \multirow[t]{2}{*}{ total $\%$} & \multirow[t]{2}{*}{23.4} & 17.35 & 10.20 & \multirow[t]{2}{*}{12.24} & \multirow[t]{2}{*}{15.31} & \multirow[t]{2}{*}{10.20} & \multirow[t]{2}{*}{6.12} & \multirow[t]{2}{*}{5.10} & \multirow{2}{*}{100.00} \\
\hline & & 27. & & & & & & & \\
\hline
\end{tabular}

Source: own study. 
It is noteworthy that many of the image characteristics were related to special types of generalisations, sometimes exclusive (negations communicating only realist; the 1st person plural form expressing the frank characteristic), sometimes resulting from the quantitative predominance of a given type of a generalisation (a rule which communicates several characteristics, but mostly just one: intelligent; taboo: bluntly states her/his bold judgements), or qualitative (strong pejorative lexical markedness: critical).

As for the remaining characteristics communicated through generalisations (insightful, writes in an interesting way), it is difficult to indicate any exclusive quantitative or qualitative types of generalisations. It seems, though, that the phenomenon is easily explainable. Insightful and writes in an interesting way may possess a similar semantic scope, within a limited area, of course. It is difficult to write in an interesting way and not include remarks which are insightful, acute, or evaluating. The ability to write in an interesting way can be associated with not only proficiency in applying specific devices which embellish a text, but it also consists of formulating acute judgements. Thus those two image characteristics utilise a similar type of a generalisation.

Therefore, the inclusion of a specific image-based communicative marker depends on the characteristics of the author of a text being communicated. The differences were of a quantitative or qualitative nature; there also appeared characteristics which were communicated exclusively by one of the modes of the functioning of generalisations. Similar modes of fulfilling generalising judgements appeared in the case of image characteristics with a similar semantic scope. The application of the study to the area of other genres (e.g. a review, a commentary) or comparing the results regarding generalisations with the data of other verbal image markers, which could constitute the basis of new studies, could surely lead to interesting cognitive and practical conclusions.

\section{Bibliography}

Awdiejew A., Habrajska G., "Obrazy ideacyjne w interpretacji tekstu”, in: "Rozmowy o komunikacji 5. Kategorialne aspekty komunikacji”, G. Habrajska (ed.), Primum Verbum, Lodz 2011, pp. 57-66.

Babbie E., "The Practice of Social Research", 9th. ed., Wadsworth/Thomson Learning, Belmont, CA 2001.

Barańska-Szmitko A., "Image from Words. What do Authors of Columns Communicate about Themselves to their Readers?", Humanities \& Social Sciences Review 2014, Vol. 3, No. 4, pp. 67-74.

Barańska-Szmitko A., "Means of Communicating an Image of Being 'Engaged' and 'A Realist' in Newspaper Columns: Results of Empirical Research", Humanities and Social Sciences Review 2016, Vol. 6, No.1, pp. 127-136. 
Barańska-Szmitko A., "The Capacities and Limitations of the Newspaper Column as a Tool for Creating the Image of Its Author", Acta Universitatis Lodziensis. Folia Litteraria Polonica 2016, No. 5 (35), pp. 115-129.

Barańska-Szmitko A., "The Capacities and Limitations of the Newspaper Column as a Tool for Creating the Image of Its Author", Acta Universitatis Lodziensis. Folia Litteraria Polonica, 2016, No. 5 (35), p. 115-129.

Corbett E.P.J., Connors R.J., "Classical Rhetoric for the Modern Student”, $4^{\text {th }}$ ed., Oxford University Press, New York 1998.

Creswell J.W., "Research design: Qualitative, Quantitative and Mixed Methods Approaches", $4^{\text {th }}$ ed., Sage, Los Angeles, London, New Delhi, Singapore, Washington D.C. 2014.

Dąbrowska A., "Zmiany obszarów podlegających tabu we współczesnej kulturze", in: "Język a Kultura. Tom Jubileuszowy. Tom 20", A. Dąbrowska (ed.), Wydawnictwo Uniwersytetu Wrocławskiego, Wroclaw 2008, pp. 173-196.

Fleischer M., "Obszar tabu w systemie polskiej kultury", in: "Literatura, kultura, komunikacja. Księga Pamiątkowa ku czci Profesora Jerzego Jastrzębskiego w 60. rocznicę urodzin”, M. Graszewicz, K. Stasiuk (eds.), Wydawnictwo Uniwersytetu Wrocławskiego, Wroclaw 2006, pp. 283-300.

Fleischer M., "Konstrukcja rzeczywistości 2", Wydawnictwo Atut, Wroclaw 2008.

Fleischer M., "Ogólna teoria komunikacji”, Wydawnictwo Uniwersytetu Wrocławskiego, Wroclaw 2008.

Fleischer M., “Typologia komunikacji”, Primum Verbum, Lodz 2012.

Flick U., "Designing Qualitative Research", Sage, Los Angeles, London, New Delhi, Singapore, Washington D.C. 2007.

Goffman E., "The Presentation of Self in Everyday Life", Anchor Books, New York 1959.

Hovland L.C., Weiss C.W., "The influence of source credibility on communication effectiveness", Public Opinion Quarterly 1951, Issue 15, pp. 635-650.

Leary M., "Self-presentation: Impression Management And Interpersonal Behavior", Westview Press, Boulder 1996.

Malhotra N., Hall J., Shaw M., Oppenheim P., "Marketing Research: An applied orientation", $3^{\text {rd }}$ ed., Pearson Education Australia Pry Ltd., New South Wales, Australia 2005.

Miodunka W., "Teoria pól językowych. Społeczne i indywidualne ich uwarunkowania”, PWN, Warsaw 1982.

Pisarek W., "Eksperyment - metoda nie tylko fonetyczna”, Biuletyn PTJ 1969, Vol. 28, pp. 181-188.

White H.A., Andsager J.L., "Newspaper Column Readers' Gender Bias: Perceived Interest and Credibility", Journalism \& Mass Communication Quarterly, Vol. 68, Issue 4, 1991, pp. 709-718.

Wilson A., Johns R., Miller K.W., Pentecost R., "Marketing research: an integrated approach: solving business problems. The value of marketing research", Pearson Education Australia Pry Ltd., New South Wales, Australia 2010.

\section{Quoted columns}

Hołownia S., "Hotelowa Biblia", Wprost 2013, Issue 9, p. 39.

Hołownia S., "Nie zarazić się złem", Rzeczpospolita 2013, Issue 23, p. 2.

Hołownia S., “O. Rydzyk jest naszym lustrem”, Newsweek 2012, Issue 20, p. 31.

Hołownia S., “To nie piekarnia”, Wprost 2013, Issue 11, p. 69. 
Środa M., “Kościół błądzi”, Wprost, 2013, Issue 16, p. 45.

Środa M., “O Polkę niepodległą!”, Wprost 2013, Issue 11, p. 53.

Środa M., "Ofensywa rynsztoka pod skrzydłami PiS”, Wprost 2013, Issue 22, p. 42.

Środa M., "Rzecz o myśleniu”, Wprost 2012, Issue 19, p. 44.

Środa M., “Świat na opak wywrócony!”, Wprost 2013, Issue 20, p. 19.

Varga K., "Klątwa Klossa, czyli ofiary adoracji”, Duży Format 2012, Issue 75, p. 23.

Varga K., "Ocieranie się, czyli sztuka słuszna i niska”, Duży Format 2013, Issue 219, p. 3.

Varga K., "Trzech kumpli czyli upiorna Mitteleuropa”, Duży Format 2012, Issue 124, p. 24.

Zaremba P., "Hrabia Fredro krzepi", Sieci 2013, Issue 18, p. 51.

Zaremba P., "Serialowy powrót kanibala", Sieci 2013, Issue 16-17, p. 77.

Anna Barańska-Szmitko

The application of generalising judgements and their influence on the images of selected Polish columnists (a constructivism-focussed quantitative and qualitative approach)

(Summary)

The goal of the text was to indicate the image characteristics of an author of a verbal expression which were communicated through expressing generalising judgements, and to establish the difference between such generalisations depending on the given image characteristic. I used constructivism as the leading theory. In terms of methodology, I applied mixed methods: quantitative (quasi-experiment) and discourse analysis. The analysis indicated that generalisations are used for communicating the characteristics of: intelligent, critical, bluntly states her/his bold judgements, insightful, writes in an interesting way, realist, frank, while the receivers assign some of the characteristics depending on the degree of evaluation emphasis, reference to a taboo, utilisation of negation, and expressions using the 1st person plural.

Keywords: competences, columnist, column, discourse analysis, image. 